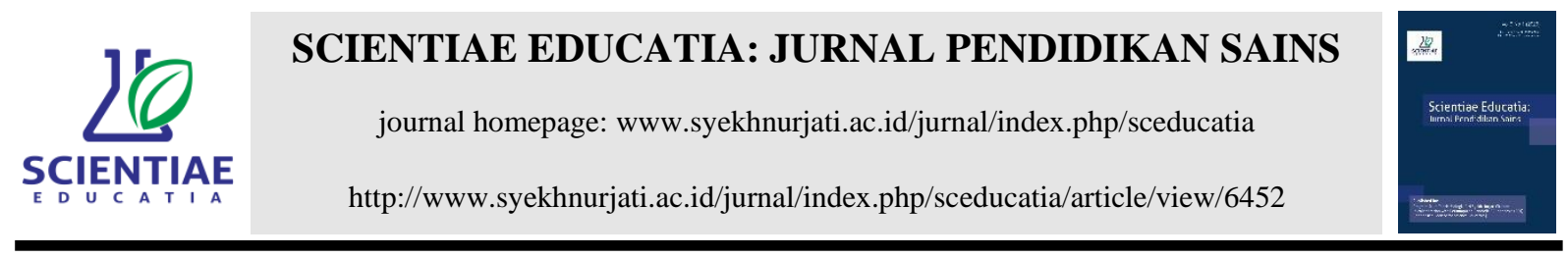

\title{
Problem-Based Learning Supported with Experiment Media Based on the Internet of Things to Enhance the Students' HOTS Ability
}

\author{
Yeni Rima Liana ${ }^{\mathrm{a}, \mathrm{b}^{*}}$, Suharto Linuwih ${ }^{\mathrm{a}}$, Sulhadi ${ }^{\mathrm{a}}$ \\ a Masters of Physics Education Study Program, Postgraduate, Universitas Negeri Semarang, Jawa Tengah, Indonesia. \\ b SMA Negeri 2 Batang, Batang, Jawa Tengah, Indonesia.
}

*Corresponding author: Jalan Kelud Utara III, Semarang, Jawa Tengah, 50237, Indonesia.. E-mail addresses: yrimaliana21@gmail.com

\section{a r t i c l e i n f o}

Article history:

Received: 07 May 2020

Received in revised form: 23 May

2020

Accepted: 31 May 2020

Available online: 30 June 2020

Keywords:

HOTS ability

Internet of Things

Experiment media

Thermodynamics

\section{a b $\mathbf{s} \mathbf{t} \mathbf{r} \mathbf{a} \mathbf{c}$}

\begin{abstract}
This study aims to analyze the feasibility and effectiveness of experiment media based on Internet of Things (IoT) to enhance the students' HOTS ability on thermodynamics law material. This Research and Development comprises of the following stages: (1) defining needs, (2) designing products, (3) developing products, and (4) disseminating products. Four expert lecturers and two physics teachers serve as the validator. The limited trial subjects consisted of six students of class XI MIPA SMAN 1 Pekalongan; the field test subjects consisted of 108 students who were randomly selected from all XI MIPA classes at SMAN 2 Batang, and the disseminating subjects were teachers of MGMP physics in Batang. The instruments used were expert validation questionnaires, teacher response questionnaires, student response questionnaires, and written tests. The results of the validation of media experts were 3.81 (very good), and material experts were 3.54 (very good). Meanwhile, the results of teacher responses were 3.92 (very good), and the results of student responses were 3.50 (very good). The effective contribution of the IoT-based experimental media to improve the ability of HOTS can be seen from the results of the Multivariate Test analysis on GLM based on the partial eta squared value of $85.9 \%$. This shows that experiment media based on IoT is feasible and effective to enhance the students' HOTS ability.
\end{abstract}

2020 Scientiae Educatia: Jurnal Pendidikan Sains

\section{Introduction}

Education in the industrial revolution era 4.0 was marked by the emergence of new literacy, namely data literacy, technological literacy, and human literacy (Zimmermann \& Torsten, 2018). The development of Information and Technology of the $21^{\text {st }}$ Century has entered the era of the Internet of Things (IoT) (Muchlis et al., 2017). IoT is a data transfer technology via the internet that connects various objects ('things') and does not require public IP on the client-side so that can be accessed anytime and anywhere using a ThingSpeak server (He et al., 2016; Gómez et al., 2013). ThingSpeak is a server dedicated to the Internet of Things devices that connect microcontrollers to the internet (Alrikabi et al., 2020; Saputra \& Hertanto, 2018). Thingspeak can be used to create IoT projects and can be downloaded for free (Prihatmoko, 2016). The presence of IoT provides a new colour in the development of instructional media innovation (Artono \& Putra, 2017). Opportunities for IoT need to be used more broadly in learning in schools (Muchlis et al., 2015). Physics learning media that utilize IoT can increase students' interest and motivation to learn and strengthen their knowledge 
(Charmonman et al., 2020). In line with this, Mohamed et al. (2018) state that IoT has the ability to improve the quality of the learning experience that enables real-time insights and can be followed up through performance. Students can visualize and process data uploaded using smartphone devices (Saraubon, 2019). This explanation concludes that the use of media in learning is very helpful for students in learning about difficult and abstract physics material.

Data in the field show that students are still weak in HOTS abilities such as analyzing, evaluating, and creating (Ariyana et al., 2019). The report on the results of the ComputerBased National Examination (UNBK) in 2019 shows that, at the national level, the most difficult physics learning material is thermodynamics. The number of students who answered the thermodynamics material correctly was only $42.51 \%$. Meanwhile, the analysis of the items for each indicator showed that the quantities that must be changed so that the efficiency of the Carnot engine increases, only reach $28.11 \%$ (Puspendik, 2019).

Furthermore, based on observations at a number of senior high schools in Batang Regency, there are no available experiment media that can help explain the concept law of thermodynamics. The learning process is still using the lecture method and practice questions only, not yet linking to the problem solving of daily life. Also, time constraints and basic competency demands that have not been met are also problems that must be solved by the teacher in delivering thermodynamics material through the experimental method. This is in line with a study by Malik et al. (2019) which states that problem-solving laboratory requires adequate time management and conditioning of students during laboratory activities. The teacher must design experiments in the laboratory according to the planned time (Tatar \& Oktay, 2011). Based on this data, it can be concluded that there is a need for innovation in developing experimental media to explain thermodynamics material.

Thermodynamics is a branch of physics that studies the relationship between energy and work of a system (Sears \& Salinger, 2013). Thermodynamics has various concepts, and some of them are very abstract, such as the concepts of heat and entropy (Hakim et al., 2017; Azizah et al., 2017). A study by Sari et al. (2013) found that the majority of students had difficulty in understanding the concept of entropy (the second law of thermodynamics). In line with the study, Musyafak et al. (2013) and Christensen et al. (2009) state that conceptual thermodynamics errors often made by physics students are temperatures, heat, and the first law of thermodynamics. This causes difficulties in the learning process (Goovaerts et al., 
2019; Georgiou, 2014). This is due to the teacher's lack of opportunity to allow students to have real experience through experimental activities (Georgious \& Sharma, 2015; Layali \& Kartika, 2015). The use of Android-based technology, combined with experiment learning, can help teachers overcome the difficulties in visualizing abstract concepts (Religia \& Achmadi, 2017; Rusydi, 2017).

The above studies indicate that, in the industrial revolution era 4.0, developing learning media through the use of recent technology is necessary to develop the students' learning interest. Employing IoT as learning media has become one of the alternatives currently considered by teachers and students. It is because the millennial generation is a digital generation that is technologically literate and likes to linger with smartphones, laptops, and gadgets. The utilization of IoT as experiment media is expected to provide students with real learning experiences on the application of the law of thermodynamics in everyday life. Experimental results can be accessed in real-time by students in graphical form via smartphones sent by the Arduino client. The teacher can control the experimental data of students through the ThingSpeak server, and students can save the experimental data on a smartphone that can be opened anytime and anywhere. The application of problem-solving in experimental activities is expected to enhance the students' HOTS abilities in solving problems related to the law of thermodynamics.

This study aims to analyze the feasibility and effectiveness of experiment media based on IoT to enhance the students' HOTS abilities on the material of the zeroth law of thermodynamics, the first law of thermodynamics and the second law of thermodynamics.

\section{Method}

This study uses Research and Development with the 4-D model (Define, Design, Develop, and Disseminate) developed by Thiagarajan in 1974 (Arifin, 2016), as shown in Figure 1. The product being developed is thermodynamics law experiment media based on IoT equipped with manual books and student worksheets.

The research subjects were four lecturers as expert validators, two physics teachers, and three groups consisting of 108 science XI grade students of Senior High School in Batang. At the same time, the subjects of dissemination were the teachers of Batang Regency physics MGMP. 


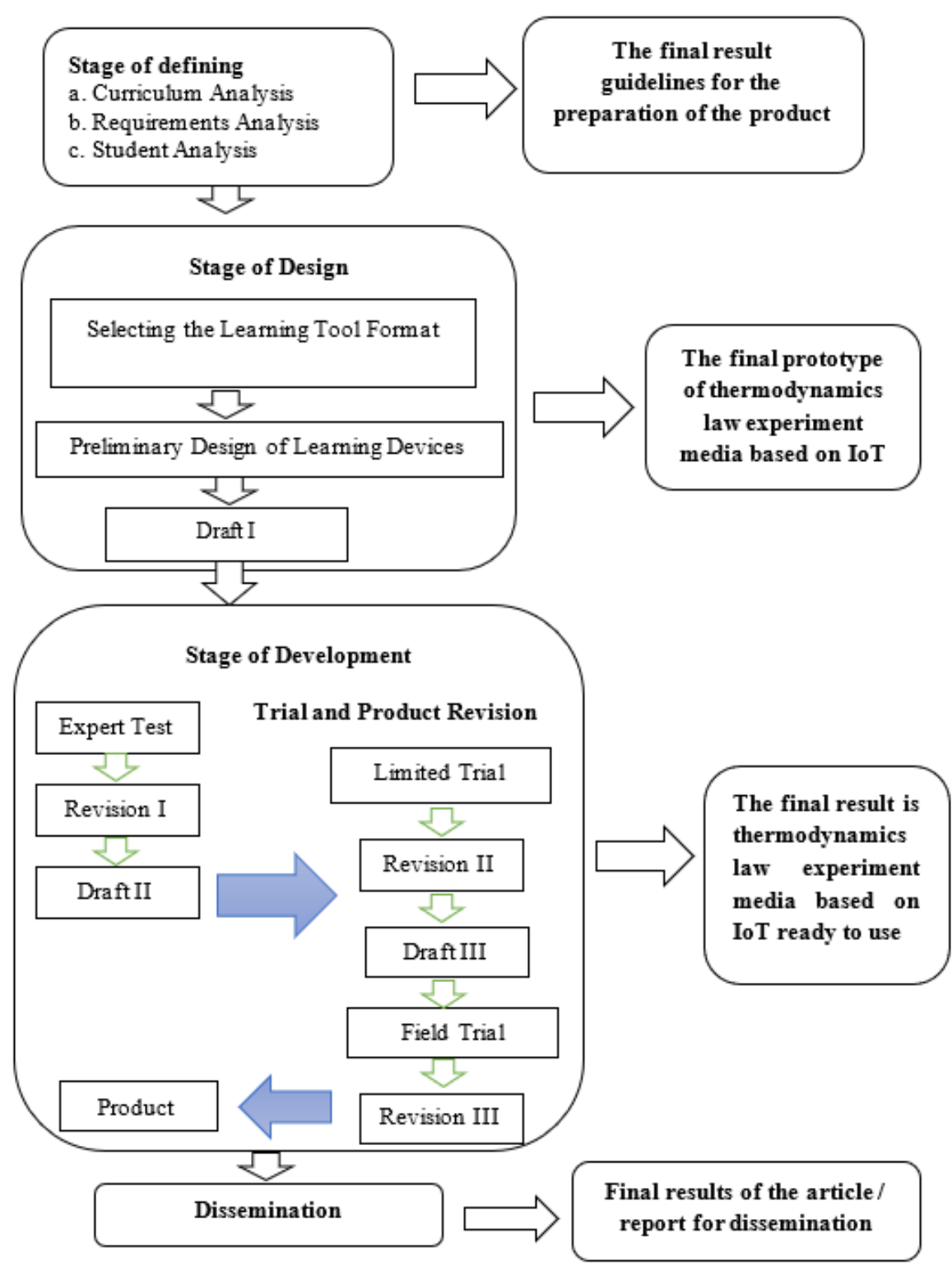

Figure 1. 4-D model development stage

Both tests and nontest were used as data collection techniques. Data collection instruments were observation sheets, validation questionnaires for media experts and material experts, teacher response questionnaires, student response questionnaires, and HOTS ability is written tests. Meanwhile, the data analysis technique of the results of the media feasibility assessment was based on the results of expert validation, teacher responses, and student responses using assessments with scores ranging from 1 to 4 . The average score of each item for all aspects of product assessment was calculated by dividing the total score of all aspects of the assessment by the number of evaluators.

$$
\bar{X}=\frac{\sum X}{n}
$$


In the above formula, $\bar{X}$ is the average score; $\sum X$ is the total score, and $n$ is the number of evaluators. The average score was then compared and converted using criteria referring to the category proposed by Widoyoko (2017), as shown in Table 1.

Table 1. Scale conversion intervals of average quality criteria questionnaire

\begin{tabular}{ccc}
\hline Score range & Categories & Index \\
\hline $\bar{X} \geq X_{i}+1,8$ Sbi & Excellent & 5 \\
$X_{i}+0,6$ Sbi $<\bar{X} \leq X_{i}+1,8$ Sbi & Good & 4 \\
$X_{i}-0,6$ Sbi $<\bar{X} \leq X_{i}+0,6$ Sbi & Fair good & 3 \\
$X_{i}-1,8$ bi $<\bar{X} \leq X_{i}-0,6 S b i$ & Less & 2 \\
$\bar{X} \leq X_{i}-1,8$ Sbi & Very Less & 1 \\
\hline
\end{tabular}

In the above table, $\bar{X}$ is the mean score; $X_{i}$ is the mean ideal score $=1 / 2$ (maximum score + minimum score), and $S b i$ is the ideal standard deviation score $=1 / 6$ (maximum scoreminimum score).

This study employed the Pre-test - Post-test control group design, as can be seen in Table 2 (Campbell \& Stanley, 2015).

Table 2. Research design

\begin{tabular}{cccc}
\hline \multirow{2}{*}{ Class } & Pre-test & \multirow{2}{*}{ Treatment } & \multicolumn{2}{c}{ Post-test } \\
\cline { 2 - 4 } & $\mathrm{Y}$ & $\mathrm{X}_{1}$ & $\mathrm{Y}$ \\
\hline Experiment & $\mathrm{T}_{1}$ & $\mathrm{X}_{2}$ & $\mathrm{~T}_{2}$ \\
Control 1 & $\mathrm{T}_{1}$ & $\mathrm{X}_{3}$ & $\mathrm{~T}_{2}$ \\
Control 2 & $\mathrm{T}_{1}$ & & \\
\hline
\end{tabular}

In the above table, $\mathrm{T}_{1}$ is pre-test; $\mathrm{T}_{2}$ is post-test; $\mathrm{Y}$ is HOTS ability; $\mathrm{X}_{1}$ are groups using IoT based learning media; $\mathrm{X}_{2}$ are groups using multimedia based on Android; and $\mathrm{X}_{3}$ are grouping using the teacher general module.

To find out the effectiveness of experiment media based on IoT in enhancing the students' HOTS ability, an analysis of assumption tests was first performed which consist of tests of normality and homogeneity of the students' pre-test and post-test results. Normality test was carried out based on Kolmogorov-Smirnov statistics. The sample is said to come from a normally distributed population if the significance value (Sig.) is more than 0.05. Meanwhile, the homogeneity test was performed to determine whether the sample used had the same variance or not. The sample used in the study is said to be homogeneous if the significance value (Sig.) is more than 0.05 based on the Levene's test.

After conducting the assumption test, the Multivariate Test analysis was then performed on the mixed design General Linear Model (GLM) based on the partial eta squared value to test the effectiveness of the media based on the results of the pre-test and post-test. IoT-based experiment media effectively improve the students' HOTS ability if the Sig. value $<0.05$. 


\section{Result and Discussion}

\section{Stage of define}

Stage of define aims to establish and define the learning requirements needed in the product development process. This stage consists of five aspects, namely: needs analysis, concept analysis, student analysis, task analysis, and analysis of learning objectives.

Needs analysis aims to identify problems that exist in schools, to get to know what is needed by students and teachers in learning. Two considerations in the needs analysis are 21 st-century curriculum and learning demands. The needs analysis data were taken from students and teachers using a questionnaire. Based on observations of laboratory equipment inventory, it was found that public and private high schools in Batang Regency did not yet have teaching aids or experimental media to explain the laws of thermodynamics. Early diagnosis shows the need for thermodynamics law experiment media that employ the use of smartphones.

Concept analysis aims to determine the material in the 2013 curriculum syllabus that is suitable with the development of experiment media based on IoT, namely KD 4.7 (create work/models of the application of the first dan second law of thermodynamics and their physical meaning) (Kemdikbud, 2016). Concept analysis aims to determine the material in the 2013 curriculum syllabus that is suitable with the development of experiment media based on IoT, namely KD 4.7 (creating work/models of the application of the first dan second thermodynamics law and their physical meaning) (Kemdikbud, 2016). In comparison, the analysis of students aims to determine the initial cognitive and psychomotor abilities of students and to find out students' interests in the material to be studied. Task analysis aims to develop the task after the students learn using experiment media based on IoT in the form of reports on the results of experiments and assessments of HOTS description. Furthermore, the analysis of learning objectives is used to summarize the results of the analysis of concepts and tasks in developing research instruments and designing learning tools that will be used by researchers.

\section{Stage of design}

The initial design was made in the form of three-dimensional drawings that were developed using the SketchUp application. The product developed is the experiment media based on IoT to explain the laws of thermodynamics. This media uses an ATmega328 microcontroller, so the resulting data can be accessed online through the IoT cloud technology 
with Arduino and ThingSpeak.com, which can be accessed in real-time and interactively on a smartphone at https://thingspeak.com/channels/channel ID. Smartphones are used to monitor data in the form of charts sent by the arduino client, as shown in Figure 2.

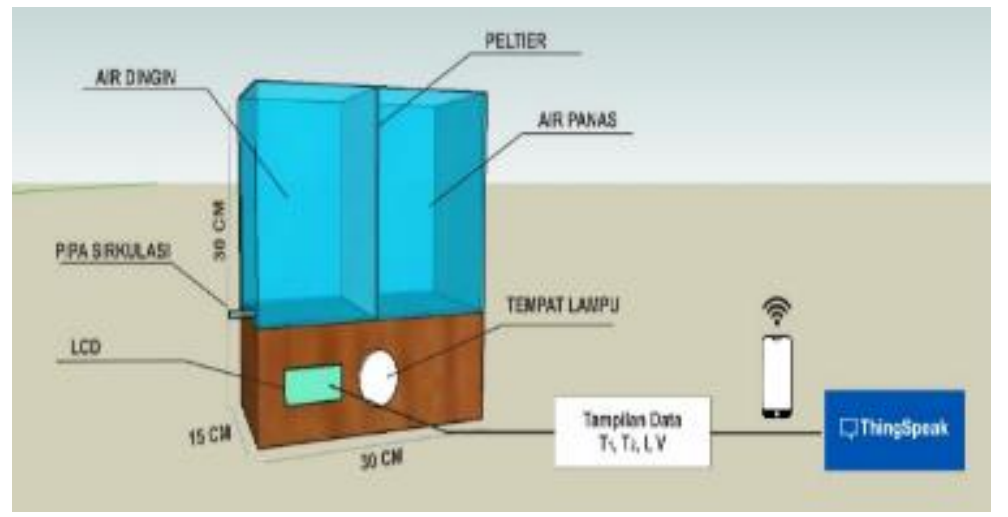

Figure 2. The experiment media based on IoT design

\section{Stage of development}

There are three parts of the experiment media based on IoT developed in the process. (1) The upper part is a hot and cold water reservoir made of acrylic with dimensions of $30 \mathrm{~cm} \times$ $15 \mathrm{~cm} \times 20 \mathrm{~cm}$ and a thickness of $5 \mathrm{~mm}$. The two reservoirs are separated by a thermal wall made of ACP material with dimensions of $20 \mathrm{~cm} \times 15 \mathrm{~cm} \times 2.5 \mathrm{~mm}$ which is connected in series with 8 TEG SP1848 peltiers. It is to convert heat energy into electrical energy due to the temperature difference between the two reservoirs. Both reservoirs are closed with ACP equipped with a hole to enter the heater and two DS18B20 temperature sensors. (2) The bottom is an electrical box and a microcontroller made of acrylic with dimensions of $30 \mathrm{~cm} \times$ $15 \mathrm{~cm} \times 10 \mathrm{~cm}$ placed under the water reservoir. The electrical components of the front consist of LCD displays, TEG sockets, Jumper cables for TEG, sockets lamp sockets, 12V DC, LED lamp fittings, and Jumper cables for light sockets. Whereas the rear electrical component consists of $220 \mathrm{~V}$ AC sockets, on/off buttons, temperature control buttons, temperature sensor sockets, water heater sockets, TEG sockets, JST Port TEG, and 5V DC output terminals for circulating water pumps. (3) The data storage section is Arduino (ATmega328 microcontroller board) and ThingSpeak. ThingSpeak is an IoT service analysis platform that allows students to collect, store, and analyze data in real-time in the "cloud". The data generated are sent by the Arduino client in the form of a sensor logging data graph that can be accessed anywhere and at any time, as long as the internet connection is available or the Android smartphone has an internet quota. 
At this stage, the media is tested to find out whether the data obtained are in accordance with the theory or not, before validation. The product design is then realized to create IoT based learning media to study the laws of thermodynamics, as shown in Figure 4.

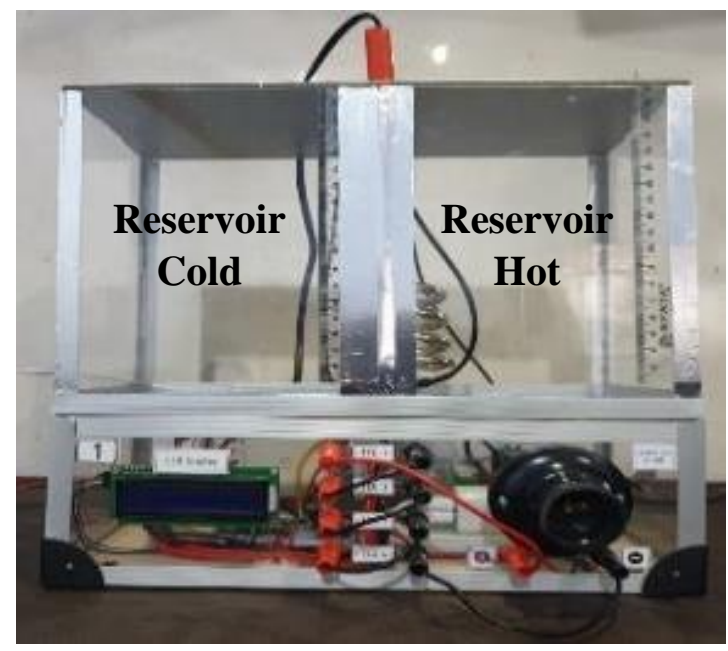

Figure 4. (a) The front of experiment media based on IoT

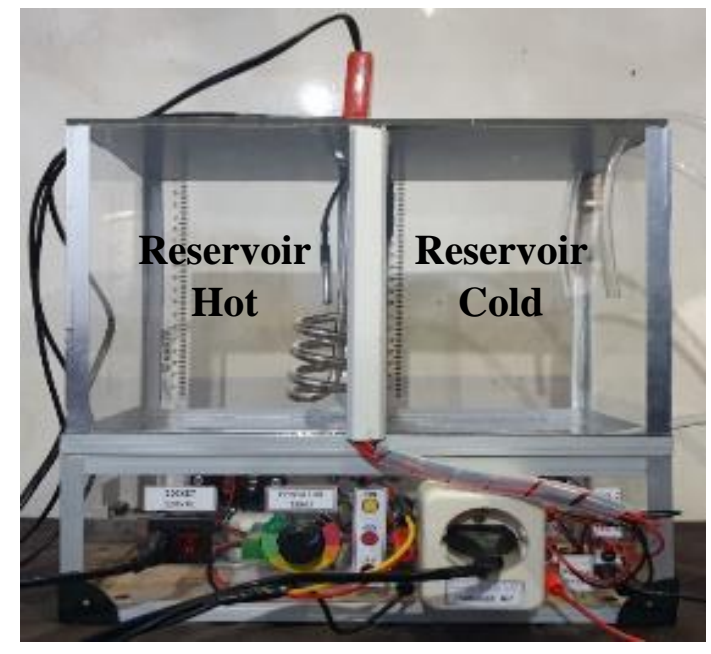

Figure 4. (b) The rear of experiment media based on IoT

The process of developing experiment media based on IoT should fit the characteristics of the feasibility of instructional media, which are made of strong enough material with attractive shapes and colours. In addition, to be simple and easy to use, the instructional media should be able to explain thermodynamics law concepts and can be used as a basis for problem-solving. The media are equipped with student worksheets containing learning objectives, problem formulation to solve problems, theoretical basis, instructions for use, thermodynamics law experimental procedures, analysis of experimental results, and conclusions, as shown in Figure 5.
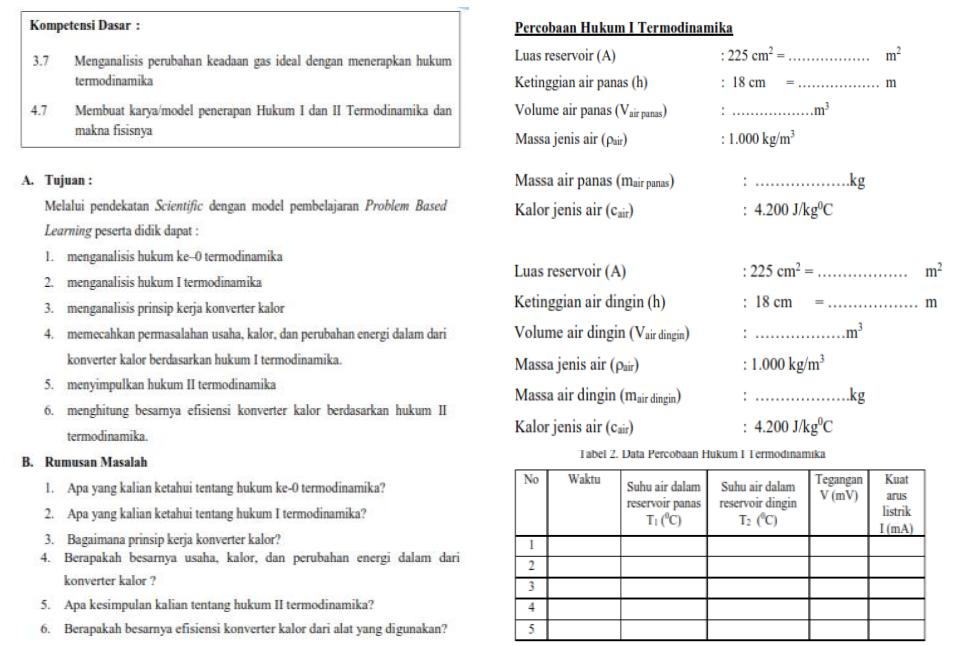

Figure 5. Student worksheets with problem based learning models 
The revised version of the experiment media based on IoT was then validated by four expert judgments (two material experts and two media experts) and two professional physics teachers. Each expert was given a questionnaire sheet containing statements relating to the suitability of the media, reviewed from the media and material aspects. Data were obtained from the assessment of experiment media based on IoT in the form of an assessment with scores ranging from 1 to 4 . After that, the average score to the criteria was converted into categories by using the five-scale grading criteria technique (Widoyoko, 2017).

Table 4. Eligibility criteria for evaluating raw scale five

\begin{tabular}{cc}
\hline Range of scores & Category \\
\hline $\bar{X}>3,4$ & Very good \\
$2,8<\bar{X} \leq 3,4$ & Good \\
$2,2<\bar{X} \leq 2,8$ & Fair \\
$1,6<\bar{X} \leq 2,2$ & Less good \\
$\bar{X} \leq 1,6$ & Not good \\
\hline
\end{tabular}

Analysis of the results of the appropriateness assessment of Media Based on the Internet of Things is presented in Table 5.

Table 5. Analysis results of IoT based experiment media assessment according to media experts

\begin{tabular}{|c|c|c|c|c|}
\hline Aspect & Item & Average per item & Average per aspect & Category \\
\hline The resilience of media components & 1 & 4.00 & 4.00 & Very good \\
\hline \multirow[t]{2}{*}{ Ease of conducting experiments } & 2 & 4.00 & \multirow{2}{*}{4.00} & Very good \\
\hline & 3 & 4.00 & & \\
\hline \multirow[t]{2}{*}{ Sensor accuracy } & 4 & 3.50 & \multirow{2}{*}{3.50} & Very good \\
\hline & 5 & 3.50 & & \\
\hline \multirow{4}{*}{$\begin{array}{l}\text { Ease of reading experiment results } \\
\text { data } \\
\text { Ease of care }\end{array}$} & 6 & 4.00 & \multirow{2}{*}{3.88} & \multirow[t]{2}{*}{ Very good } \\
\hline & 7 & 3.75 & & \\
\hline & 8 & 4.00 & \multirow{2}{*}{3.88} & \multirow[t]{2}{*}{ Very good } \\
\hline & 9 & 3.75 & & \\
\hline Safety for students & 10 & 4.00 & 4.00 & Very good \\
\hline \multirow[t]{2}{*}{ Aesthetics } & 11 & 4.00 & \multirow{2}{*}{4.00} & \multirow[t]{2}{*}{ Very good } \\
\hline & 12 & 4.00 & & \\
\hline \multirow[t]{2}{*}{ Efficient } & 13 & 3.50 & 3.50 & Very good \\
\hline & aspects & & 3.84 & Very good \\
\hline
\end{tabular}

The assessment results obtained are quantitative data with a score of 1 to 4 . The data are then converted and analyzed using a five-scale rating category, as shown in Table 4. Product evaluation based on sub-aspects of sensor accuracy and experiment time efficiency gets an average score of 3.50 , classified in a very good category. Ratings provided by the validator are included with suggestions for improvement. As suggested by the validator, the socket should be designed more friendly so that it can be easily installed and removed by students. The experiment time is thus more efficient and does not affect the sensitivity of the sensor. The aspect of reading ease of experiment results on ThingSpeak obtains a mean value of 3.75, 
classified in a very good category. It is suggested by the validator that, when conducting the experiments, the internet connection must be stable. The overall analysis of all aspects gets a mean value of 3.81 and shows that experiment media based on IoT are categorized as excellent. These results prove that experiment media based on IoT are appropriate to be used in physics learning activities.

Analysis of the results of the assessment of the feasibility of the material aspects of experiment media based on IoT that have been categorized is presented in Table 6 .

Table 6. Analysis result of IoT based experiment media assessment according to media experts

\begin{tabular}{ccc}
\hline Aspect & Average per aspect & Category \\
\hline Media compatibility with the curriculum & 3.81 & Very Good \\
Media compatibility with the material & 3.75 & Very Good \\
HOTS as problem-solving & 3.69 & Very Good \\
Average of all aspects & 3.75 & Very Good \\
\hline
\end{tabular}

As can be seen in Table 6, the assessment of experiment media based on IoT on aspects of curriculum analysis and needs analysis using a scale five assessment category obtains a mean value of 3.81, classified in a very good category. Ratings provided by the validator are included with suggestions for improvement. It is suggested by the validator that researchers should add basic competency skills. Aspects of the suitability of the media with learning material obtain an average value of 3.75, classified in a very good category. It is suggested by the validator that there should be an explanation that water can represent the ideal gas system. In the problem-solving aspect, the mean score is 3.69, classified in a very good category. The researchers are suggested to improve the steps of the experiment in detail to make it easier for students to understand the material. The overall analysis of all aspects obtains a mean value of 3.75. The IoT-based experiment media developed are categorized as excellent. These results prove that the IoT-based experimental media with the problem-based learning approach is suitable for use in physics learning activities.

This limited trial aims to find out the students' responses to the thermodynamics experiment media based on IoT, which were previously revised based on the results of expert validation. The ease of carrying out experiments is based on aspects of learning, experimental guidelines, and experimental data obtained. During the learning process, students used experimental media to learn thermodynamics. Researchers observed the students' attitudes toward the product being developed and provided guidance if problems arose when using the media. At the end of the learning session, students filled out a questionnaire about the use of 
thermodynamics law experiment media based on IoT. The researchers' observations and the results of student responses during the limited trial activities are presented in Table 7.

Table 7. Students' responses to limited trials

\begin{tabular}{cccc}
\hline Aspect & Number of participants & Average per aspect & Category \\
\hline Learning & \multirow{2}{*}{6} & 3.76 & \multirow{2}{*}{ Very Good } \\
Experimental guidelines & \multirow{2}{*}{3.50} & \\
ThingSpeak data & & 3.24 & \\
\hline
\end{tabular}

Table 7 shows that the average value of the learning aspect is 3.76 (a good category); the experimental guidance aspect obtains an average per an aspect of 3.50 (a very good category), and the average score of ThingSpeak data aspect is 3.24 (a good category). There are two suggestions from students regarding experiment media based on IoT: to improve the TEG socket so that it is easier to insert the jumper cable and to add a water pump so that the reservoir does not need to be removed from the electricity after the experimental activities are finished. The overall student assessments of experiment media based on IoT are categorized as very good. The product is thus suitable for use in physics learning activities with problembased learning models.

The field trial aims to find out the effectiveness of the IoT based learning media in increasing the students' HOTS ability. Data from the test results in the field are learning outcomes based on the students' cognitive abilities, namely learning outcomes, the ability to analyze, evaluate, and create. Field testing is carried out by applying the three steps, namely pre-test, treatment, and post-test. In the pre-test, the students' initial HOTS ability on thermodynamics

Law material is measured. HOTS test items consist of 10 items of analyzing, evaluating, and creating. In the treatment, students do experimental activities with a problem-based learning model using IoT-based experimental media in the experimental class. The control class 1 uses interactive multimedia based on Android, whereas the control class 2 uses the teacher's general module. In the post-test, the students' HOTS ability on thermodynamics law material after the end of learning activities is measured. The results are presented in Table 8 .

Table 8 . Test results of the students' HOTS ability

\begin{tabular}{cccc}
\hline Component & Class & Average & Standard deviation \\
\hline \multirow{2}{*}{ Pre-test } & Experiment & 40.71 & 3.81 \\
& Control 1 & 45.15 & 5.59 \\
& Control 2 & 40.31 & 2.44 \\
\multirow{2}{*}{ Post-test } & Experiment & 71.31 & 5.22 \\
& Control 1 & 51.03 & 7.55 \\
& Control 2 & 56.44 & 8.27 \\
\hline
\end{tabular}


Table 8 shows that the increase in the student's HOTS ability in the experimental class is higher than the control class 1 and control class 2 . This shows that the use of experiment media based on IoT has a significant influence on the improvement of the students' HOTS ability. These results are in line with research by Saputro et al. (2019) that providing direct learning experiences with teaching aids could lead to students' better understanding and create more meaningful learning experiences. Agreeing with this, direct learning experiences can be provided through experimental activities in the laboratory with the HOTS approach as problem-solving (Dinatha \& Kua, 2019). The higher the HOTS ability of students, the better their academic performance in physics (Ramos et al., 2018) Learning with LMS-google classroom integrated with flipped-problem based learning can improve the students' HOTS skills (Ramadhani et al., 2019).

To find out the effectiveness of the experiment media based on IoT in increasing the students' HOTS ability, a multivariate test statistic test was analyzed on the Mixed Linear General Model (GLM) based on partial eta squared values. Assumption tests become the prerequisites before conducting statistical tests related to hypotheses in the research. The tests consist of tests of normality and homogeneity of the students' pre-test and post-test results data.

Table 9. HOTS Test Results

\begin{tabular}{ccccc}
\hline \multirow{2}{*}{ Test } & \multirow{2}{*}{ Class } & \multicolumn{2}{c}{ Kolmogorov-Smirnov } \\
\cline { 3 - 5 } Pre-test HOTS & Experiment & Statistics & df & Sig. \\
& Control 1 & 0.12 & 30 & 0.20 \\
& Control 2 & 0.15 & 32 & 0.06 \\
\multirow{2}{*}{ Post-test HOTS } & Experiment & 0.14 & 30 & 0.12 \\
& Control 1 & 0.15 & 30 & 0.08 \\
& Control 2 & 0.13 & 32 & 0.17 \\
\hline
\end{tabular}

Table 9 shows the results of the normality test based on Kolmogorov-Smirnov statistics on the sample used. As seen in Table 9, the results of the analysis show the significance value (Sig.) for each $\mathrm{p}>0.05$ which means that the sample used in the study came from populations that were normally distributed.

The next assumption test is the homogeneity test. Homogeneity test is performed to determine whether the sample used has the same variance or not. Homogeneity test results are presented in Table 10.

Table 10. Homogeneity test analysis results

\begin{tabular}{ccccc}
\hline Test & F & df1 & df2 & Sig. \\
\hline Pre-test HOTS & 0.07 & 2 & 89 & 0.926 \\
Post-test HOTS & 0.02 & 2 & 89 & 0.917 \\
\hline
\end{tabular}


Table 10 shows the homogeneity test results based on Levene's statistical test. The results of the analysis in Table 10 show a significance value (Sig.) for each $p>0.05$ which means that the sample used in the study came from populations that had the homogeneous variance.

The effective contribution of the use of experiment media based on IoT, interactive multimedia based on IoT, and teacher general modules in learning activities as a means for enhancing the students' HOTS ability on thermodynamics law material can be seen from the results of the Multivariate Test Analysis on GLM based on partial eta squared values, as shown in Table 11.

Table 11. Multivariate HOTS tests

\begin{tabular}{clcc}
\hline Class & & Sig. & Partial eta squared \\
\hline Experiment media based on IoT & Hotelling's trace & 0,000 & 0.859 \\
Interactive multimedia based on Android & Hotelling's trace & 0,000 & 0.175 \\
Teacher general module & Hotelling's trace & 0,000 & 0,608 \\
\hline
\end{tabular}

Table 11 shows the largest contribution made by the IoT-based learning media in increasing the students' HOTS ability, amounting to $85.9 \%$. The use of IoT as experimental media makes learning more interactive and interesting. Most importantly, it reduces the work effort so that the experimental activities become more efficient. Students can directly see the sensor output in the form of parameters of temperature, electric voltage and electric current strength on the LCD display, and graphical outputs that are the results of experiments on Thingspeak Cloud through smartphone Subscriber. The syntax of HOTS questions as problem-solving in the experiment guide book leads to the process of understanding problembased concepts and making them hypotheses. The syntax of HOTS as problem solving also builds a social system between teachers and students during the learning process. Through experimental activities, students can develop 4Cs skills (critical thinking, communication, collaboration, and creativity).

The effective contribution made by Android-based interactive multimedia in increasing the students' HOTS ability is $17.5 \%$. Meanwhile, the effective contribution of the general module of the teacher is $60.8 \%$. This is due to the lack of interaction between the teacher and students in the control class, even between the students themselves. Android-based interactive multimedia and the general modules of the teachers do not provide opportunities for students to develop HOTS skills like problem-solving. Students do not get direct experiences regarding the application of thermodynamics law material in everyday life. What's more, the control class learning that uses Android-based interactive multimedia takes place at $2 \mathrm{pm}$ 
when students are already tired and bored. Thus, the students' ability to understand thermodynamics law material is low. Whether or not the subject matter is effectively understood by students is also affected by learning time at school.

The effectiveness of experiment media based on IoT to enhance the students' HOTS ability in thermodynamics law material in this study agrees with the results of research by Saputro et al. (2019) and (Preciado Babb et al., 2014) stating that providing hands-on experience through experiments using the Carnot machine trainer with guided inquiry learning models can provide a higher understanding of thermodynamics material than indirect experience. This statement is in line with a study by Muchlis et al. (2017) which states that the use of IoT in experimental activities enables students to observe automatic time measurement results and observational data directly and in real-time through the Newton App application on Androidbased mobile phones so that they have direct experience in the experiments. In addition, Gómez et al. (2013) dan Afrizal (2018) state that the experiment media based on IoT are effective in integrating all experimental devices into the network and can be managed from websites that provide information in real-time.

\section{Stage of disseminate}

The distribution phase of experiment media based on IoT is carried out through socialization through physics MGMP at the district level.

\section{Conclusion}

Based on the results of the validation by expert validators and professional physics teachers, it can be concluded that the IoT-based experimental media developed are feasible to be used in the study of thermodynamics laws and are effective in increasing the students' HOTS ability. The advantages of the experiment media based on IoT are that the measurement of temperature parameters, electric current strength and electric voltage digitally displayed on the LCD display, and the plot graph of the experimental results can be accessed directly through the ThingSpeak website on smartphones at https://thingspeak.com/channels/ID. The effectiveness of the experiment media based on IoT can be seen from the results of the Multivariate Test analysis on the GLM based on the partial eta squared values. It is proven that the experimental class gains the highest percentage of improvement in the students' HOTS ability. For further research, it is necessary to develop the experiment media based on IoT on other physics materials that are relevant to the 
students' learning needs. The potential of IoT as the learning media can be combined with appropriate approaches and learning models.

\section{Acknowledgement}

Sincere thanks go to the headmaster of Senior High School 2 Batang for granting permission and supporting this research.

\section{References}

Afrizal, M. A. (2018). Rancang bangun rumah pintar berbasis IoT(Internet of Things) sebagai media pembelajaran pada mata pelajaran pemrograman, mikroprosesor, dan mikrokontroller di SMKN 2 Surabaya. Jurnal Pendidikan Teknik Elektro, 7(1), 79-86.

Alrikabi, H. T. S., Nasser, K. W., \& Alaidi, A. H. M. (2020). The application of wireless communication in IoT for saving electrical energy. International Journal of Interactive Mobile Technologies, 14(1), 152-160.

Arifin, Z. (2016). Evaluasi Pembelajaran: Prinsip, Teknik, Prosedur. Bandung: PT Remaja Rosdakarya Offset. Bandung.

Ariyana, Y., Pudjiastuti, A., Bestary, R., \& Zamroni. (2019). Buku Pegangan Pembelajaran Berorientasi pada Keterampilan Berpikir Tingkat Tinggi. Jakarta: Dirjen GTK Kemdikbud.

Artono, B., \& Putra, R. G. (2017). Penerapan Internet of Things (IoT) untuk kontrol lampu menggunakan arduino berbasis web. Jurnal Teknologi Informasi Dan Terapan, 5(1), 9-16.

Azizah, D. N., Sutopo, \& Zulaikah, S. (2017). Identifikasi pemahaman konsep siswa SMA pada materi termodinamika. Prosiding Seminar Pendidikan IPA Pascasarjana UM, 2, 134142. Malang: Universitas Negeri Malang.

Campbell, D. T., \& Stanley, J. C. (2015). Experimental and quasi-experimental designs for research. Ravenio Books.

Christensen, W. M., Meltzer, D. E., \& Ogilvie, C. A. (2009). Student ideas regarding entropy and the second law of thermodynamics in an introductory physics course. American Journal of Physics, 77(10), 907-917.

Dinatha, N. M., \& Kua, M. Y. (2019). Pengembangan modul praktikum digital berbasis Nature Of Science (NOS) untuk meningkatkan Higher Order Thinking Skill (HOTS). Journal of Education Technology, 3(4), 293-300.

Georgiou, H. (2014). Doing Positive Work: On student understanding of thermodynamics. The University of Sydney.

Georgious, H., \& Sharma, M. D. (2015). Does using active learning in thermodynamics lectures improve students' conceptual understanding and learning experiences? European Journal of Physics, 36(1), 015020.

Gómez, J., Huete, J. F., Hoyos, O., Perez, L., \& Grigori, D. (2013). Interaction system based on Internet of things as support for education. Procedia Computer Science, 21, 132-139.

Goovaerts, L., De Cock, M., Struyven, K., \& Dehaene, W. (2019). Developing a module to teach thermodynamics in an integrated way to 16-year-old pupils. European Journal of STEM Education, 4(1), 1-11. https://doi.org/10.20897/ejsteme/3964

He, J. (Selena), Chia, D., Lo, T., Xie, Y., \& Lartigue, J. (2016). Integrating Internet of things (IoT) into STEM undergraduate education: A case study of a modern technology infused 
courseware for embedded system course. Proceedings - Frontiers in Education Conference, FIE, 2016-Novem, 1-9. https://doi.org/10.1109/FIE.2016.7757458

Kemdikbud. (2016). Silabus Mata Pelajaran Sekolah Menengah Atas/Madrasah Aliyah (SMA/MA). Jakarta: Kementerian Pendidikan dan Kebudayaan.

Layali, S., \& Kartika, I. (2015). Pengembangan alat praktikum termodinamika berbasis problem based learning. Kaunia, 11(2), 136-143.

Malik, A., Novita, Y., \& Nuryantini, A. Y. (2019). Enhancing critical thinking skills of students related to temperature and heat topics through problem solving-laboratory model. Jurnal Penelitian \& Pengembangan Pendidikan Fisika, 5(1), 9-20.

Muchlis, F., Sulisworo, D., \& Toifur, M. (2017). Pengembangan alat peraga fisika berbasis internet of things. Jurnal Pendidikan Fisika Unversitas Muhammadiyah Makasar, 6(1), 13-20.

Musyafak, A., Linuwih, S., \& Sulhadi. (2013). Konsepsi alternatif mahasiswa fisika pada materi termodinamika. Unnes Physics Education Journal, 2(3).

Preciado Babb, A. P., Saar, C., Friesen, S., \& Brandon, J. (2014). Engaging high school students in an engineering thermodynamics project. IEEE Global Engineering Education Conference, EDUCON, 222-228.

Prihatmoko, D. (2016). Penerapan Internet of Things ( IoT ) dalam pembelajaran di UNISNU Jepara. Simetris : Jurnal Teknik Mesin, Elektro Dan Ilmu Komputer, 7(2), 567-574.

Puspendik. (2019). Laporan Penguasaan Materi Ujian Nasional. Jakarta: Kementerian Pendidikan dan Kebudayaan.

Ramadhani, R., Umam, R., Abdurrahman, A., \& Syazali, M. (2019). The effect of flippedproblem based learning model integrated with LMS-google classroom for senior high school students. Journal for the Education of Gifted Young Scientists, 7(2), 137-158.

Ramos, J. L. S., Dolipas, B. B., \& Villamor, B. B. (2018). Higher-Order thinking skills and academic performance in physics of college students: A regression analysis. International Journal of Innovative Interdisciplinary Research,4(4), 48-60.

Religia, R., \& Achmadi, H. R. (2017). Pengembangan KIT Sederhana stirling engine pada materi termodinamika sebagai media pembelajaran fisika SMA. Jurnal Inovasi Pendidikan Fisika, 6(3), 113-119.

Rusydi, R. (2017). Pembelajaran berbasis masalah (PBM) pada materi termodinamika untuk meningkatkan kemampuan kognitif dan kemampuan kreatif (kreativitas) mahasiswa FTK UIN Ar-Raniry Banda Aceh. Jurnal IPA \& Pembelajaran IPA, I(2), 192-202. https://doi.org/10.24815/jipi.v1i2.9694

Saputra, R. H., \& Hertanto, D. B. (2018). Media berbasis teknologi internet of things ( iot ) mata pelajaran teknik mikroprosesor di kelas X Audio Video SMK N 3 Yogyakarta. EJournal Universitas Negeri Yogyakarta, 8(2), 131-138.

Saputro, V. C. E., Prabowo, \& Admoko, S. (2019). Pengembangan alat peraga mesin carnot sebagai media pembelajaran dengan model pembelajaran inkuiry terbimbing. IPF : Inovasi Pendidikan Fisika, 08(02), 716-721.

Sari, D. M., Surantoro, \& Ekawati, E. Y. (2013). Analisis Kesalahan dalam Menyelesaikan Soal Materi Termodinamika pada Siswa SMA. Jurnal Materi Dan Pembelajaran Fisika (JMPF), 3(2), 33-39.

Sears, \& Salinger. (2013). Thermodynamics, Kinetic Theory, and Statistical Mechanics. In Addison-Wesley Publishing Company.

Tatar, E., \& Oktay, M. (2011). The effectiveness of problem-based learning on teaching the first law of thermodynamics. Research in Science and Technological Education, 29(3), 315-332. 
Widoyoko, E. P. (2017). Teknik Penyusunan Instrumen Penelitian. (6 th ed). Yogyakarta: Pustaka Belajar.

Zimmermann, \& Torsten. (2018). Industry 4.0: Nothing is More Steady than Change. In Smart Grid Analytics for Sustainability and Urbanization. USA: IGI Global. 